This Journal is available in Telkom University online Journals

Jurnal Manajemen Indonesia

\title{
Comparative Study of AHP and AHP-TOPSIS in Analyzing Supplier Priority (A Case Study of Diesel Fuel Supplier at PT. X)
}

Shelvy Kurniawan, Sambudi Hamali, and Sandra Gunawan

Management Department, BINUS Business School Undergraduate Program, Bina Nusantara University

\begin{abstract}
The selection of diesel fuel suppliers at PT. X was held in four operational areas, namely South Sumatra, Central Kalimantan, West Kalimantan, and East \& North Kalimantan. The purpose was to determine the criteria, sub criteria and their relative weights in the selection of the best diesel fuel suppliers for each operational area of PT. X. This study compares the use of two well-known multi criteria decision-making methods namely Analytical Hierarchy Process (AHP) and AHP-TOPSIS (Technique for Order Preference by Similarity to Ideal Solution). The criteria tested included quality, price, capability, delivery, supplier profile, and service \& relationship. The criterion with the highest weight was delivery, in which the sub criterion with the weight was the supply capability.
\end{abstract}

Keywords-AHP, TOPSIS, Supplier Selection, Best Supplier

\begin{abstract}
Abstrak
Pemilihan pemasok bahan bakar diesel di PT. X yang diadakan di empat wilayah operasional, yaitu Sumatera Selatan, Kalimantan Tengah, Kalimantan Barat, dan Kalimantan Timur \& Utara. Tujuannya adalah untuk menentukan kriteria, subkriterias dan bobot pentingnya dalam pemilihan pemasok bahan bakar diesel terbaik untuk setiap area operasional PT. X. Penelitian ini akan membandingkan penggunaan dua metode pengambilan keputusan multi-kriteria yang terkenal yaitu AHP (Analytical Hierarcy Process) dan AHP-TOPSIS (Teknik untuk Preferensi Pesanan dengan Kemiripan dengan Solusi Ideal). Kriteria yang diuji adalah Kualitas, Harga, Kemampuan, Pengiriman, Profil Pemasok, dan Layanan \& Hubungan dengan hasil kriteria tertimbang tertinggi adalah Pengiriman, kemudian diikuti oleh subkriteria tertimbang tertinggi yaitu Kemampuan Supply.
\end{abstract}

Kata kunci-AHP, TOPSIS, Penyeleksian Pemasok, Pemasok Terbaik

\section{INTRODUCTION}

The global price of crude palm oil (CPO) has been declining in recent years. The price of this superior Indonesian agricultural commodity has fallen to its lowest level in more than 3 years, or since the beginning of September 2015 (Hanung, 2018). The decline in CPO prices is influenced by several factors including the US and China trade war, abundance of CPO supply, decline in the price of soybean oil as a CPO substitute due to soybean land expansion in the United States and Argentina, and the policy of the European Union to limit palm oil exports from palm oil producing countries (Putriadita, 2018).

The global decline in CPO prices is a concern of the government and entrepreneurs engaged in the palm oil industry, including in Indonesia as Indonesia is the largest producer and exporter of palm oil in the world. In 2018, the Indonesian government took many actions with respect to CPO. In November 2018, the government reviewed the export levies on palm oil products and their derivatives (CNN Indonesia, 2018). Other government actions are reflected in the B20 policy, which is expected to be able to lift the price and absorption of CPO (CNN Indonesia, 2018).

\author{
Article info \\ Received (14/07/2019) \\ Revised (05/12/2019) \\ Accepted (07/03/2020) \\ Corresponding_author: shelvy.kurniawan001@binus.ac.id \\ DOI: https://doi.org/10.25124/jmi.v20i1.2799 \\ Copyright@2020. Published by School of Economics and Business - Telkom University
}


The high decline in CPO prices globally certainly affects companies in the palm oil industry such as PT. X, whose head office is based in Jakarta. PT. X is a company that produces CPO, which has plantations and palm oil mills distributed across various provinces in Indonesia, including the provinces of South Sumatra, Central Kalimantan, West Kalimantan, East and North Kalimantan. Amidst the falling CPO prices, it is important for companies to maintain the supply chain and minimize costs incurred. According to Renganath \& Suresh (2016), strategic decisions on supply chain management are within the control of the purchasing department, which is responsible for getting the right amount of material at the right time and of course from the right suppliers. This statement is supported by the report by Heizer et al. (2017), that the biggest proportion of the company's general income is spent on purchases, so the supply chain provides a good opportunity for savings. Effective cost cutting can help companies to achieve profit targets more easily when compared to increasing sales efforts.

In line with theory, the procurement team at PT. X, has an important role in selecting the best suppliers. The process of selecting suppliers at PT. X is a complex practice that considers the number of suppliers that must be evaluated as tabulated in Table 1.

Table 1 Number of Materials and Number of Vendors at PT. X (Period of June 2017 - October 2018)

\begin{tabular}{llrr}
\hline No. & Category & $\begin{array}{c}\text { Number of Materials } \\
\text { per Category }\end{array}$ & $\begin{array}{c}\text { Number of } \\
\text { Vendors per } \\
\text { Category }\end{array}$ \\
\hline 1 & Chemical \& Laboratory & 154 & 98 \\
2 & Plantation & 333 & 94 \\
3 & IT, GA \& Stationery & 641 & 102 \\
4 & Building \& Infrastructures & 1.229 & 218 \\
5 & HE \& Transportation & 2.685 & 96 \\
6 & Safety, Health, and Environment (SHE) & 795 & 87 \\
7 & General Equipment & 2.956 & 384 \\
8 & Machinery \& Power House & 672 & 73 \\
9 & Services & 1.106 & 415 \\
\hline & Total & 10.571 & 1.567 \\
\hline
\end{tabular}

Source: PT. X (2018)

A total of 10.571 types of material must be purchased by PT. X. The materials are divided into two main categories, namely non service and service materials. Non service materials dominate the total expenditure for purchases by $62.370 \%$, while the service materials are at $37.630 \%$ of the total expenditure. In Figure 1 , proportion of expenditure on each non service material is presented as a percentage of the total expenditure bought by PT.X in from January-June 2018.

This research focuses on selecting the best alternative diesel fuel suppliers for PT. X; this is supported by facts including the large contribution of the non service materials to the purchasing expenditure in the period of January - June 2018 which is equal to $15.250 \%$. The non service materials comprise of the second largest expenditure contribution after fertilizer, which contributes $34.947 \%$ of the expenditure. Moreover, diesel fuel has become more interesting as a subject of study by considering the large number of suppliers in each procurement period. This purchase is carried out twice a month, while the purchase of each type of fertilizer is carried out from each dedicated fertilizer supplier with only one purchase period in a year. The importance of research for the company is that in case of a delay in the procurement of diesel fuel, the company's operations would be greatly affected because diesel fuel is a vital material in the operational process that is useful as the main transportation fuel that operates in plantation and factory environments and fuel for generators which are sources of electrical energy for operations in plantations and factories.

The problem of choosing diesel fuel suppliers using various criteria and sub criteria can be solved by the multi criteria decision-making method (MCDM). Garoma and Diriba explained that MCDM was considered as one of the rapidly growing operations research areas dedicated to the provision of mathematical and analytical tools or mechanisms (Kurniawan et al., 2018). It tackled complex problems involving multiple criteria, goals, or objectives of conflicting nature. This study uses MCDM, which is focused on the use of the Analytical Hierarchy Process (AHP) method for criteria and sub criteria weighting. Furthermore, the originality of this 
study is that it will be extended by comparing the use of AHP with the technique for order of preference by similarity to ideal solution (TOPSIS), to analyze priority order or ranking for each alternative supplier, which will be applied in the CPO industry, particularly for diesel fuel suppliers.

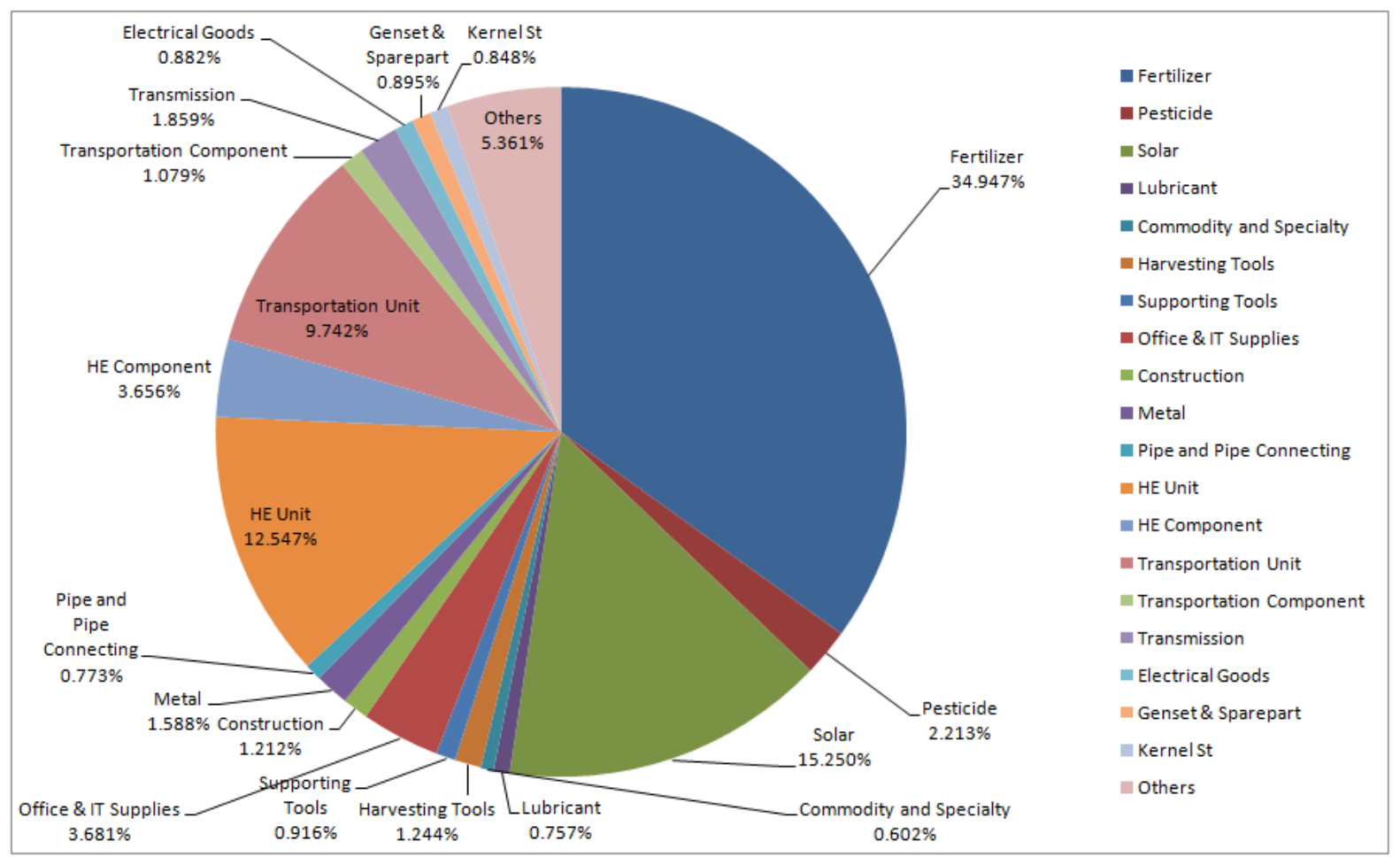

Figure 1 Non Service Material Purchase Items for Period of January-June 2018 (Source: PT. X, 2018)

The purpose of this study is to identify and find out the criteria and sub criteria that are applied by the company in the diesel fuel supplier selection process, to determine the weighting of the criteria and sub criteria used to assess diesel suppliers using the AHP method, to determine the ranking order of diesel fuel suppliers using the AHP and AHP-TOPSIS methods, and comparing the results of calculations using the AHP and AHPTOPSIS methods in selecting diesel fuel suppliers at PT. X.

\section{LITERATURE REVIEW}

This research used the AHP method and the TOPSIS method. AHP method was first introduced by Thomas Saaty in 1980, this method is known for its applicability as a tool that is very helpful in solving complex decision-making problems by evaluating and choosing the best solution from alternative solutions based on the criteria studied (Chi and Trinh, 2016). On the other hand, Gurung and Phipon (2016), it explained that TOPSIS was introduced by Hwang and Yoon in 1981, this method chooses an alternative that had the shortest geometric distance from a positive ideal solution and the farthest geometric distance from a negative ideal solution.

The use of AHP and TOPSIS in this research was based on a consideration of the popularity of the methods used in several previous researches as tabulated in Table 2. In Table 2, it can be observed that the most commonly used method is the Technique for Order of Preference by Similarity to Ideal Solution (5 studies), Analytical Hierarchy Process (4 studies), Fuzzy Analytical Hierarchy Process (3 studies), VIKOR (3 studies ), Fuzzy TOPSIS (3 studies), Analytical Network Process (2 studies), Fuzzy Analytical Hierarchy Process (2 studies), ELECTRE (1 research), Fuzzy ELECTRE (1 study), and DEMATEL (1 study). 
Table 2 Methods and Criteria used in Previous Researches for Supplier Selection

\begin{tabular}{|c|c|c|c|c|c|c|c|c|c|c|c|c|c|}
\hline \multirow[b]{2}{*}{ Method } & \multicolumn{13}{|c|}{ Criteria } \\
\hline & 尝 & $\stackrel{\mathscr{U}}{=}$ & : & 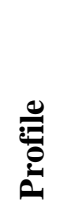 & 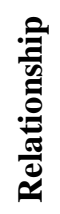 & $\overrightarrow{\tilde{\theta}}$ & 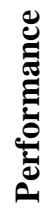 & 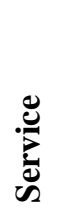 & . & : & $\stackrel{\vec{E}}{\stackrel{\Xi}{\Xi}}$ & $\underset{\overparen{E}}{\overparen{E}}$ & $\frac{y}{a n}$ \\
\hline AHP-TOPSIS & $\checkmark$ & $\checkmark$ & $\checkmark$ & $\checkmark$ & $\checkmark$ & & & & & & & & \\
\hline FTOPSIS & $\checkmark$ & & $\checkmark$ & $\checkmark$ & & $\checkmark$ & $\checkmark$ & & & & & & \\
\hline TOPSIS & $\checkmark$ & $\checkmark$ & $\checkmark$ & & & & & $\checkmark$ & & & & & \\
\hline AHP-TOPSIS & $\checkmark$ & $\checkmark$ & $\checkmark$ & & & & & $\checkmark$ & & & & & \\
\hline AHP & $\checkmark$ & $\checkmark$ & $\checkmark$ & & & & & $\checkmark$ & $\checkmark$ & & & & \\
\hline FTOPSIS-MCGP & $\checkmark$ & $\checkmark$ & $\checkmark$ & $\checkmark$ & $\checkmark$ & & $\checkmark$ & $\checkmark$ & $\checkmark$ & $\checkmark$ & $\checkmark$ & & \\
\hline FANP & $\checkmark$ & $\checkmark$ & $\checkmark$ & $\checkmark$ & & & & $\checkmark$ & $\checkmark$ & $\checkmark$ & & & \\
\hline VIKOR & $\checkmark$ & & $\checkmark$ & $\checkmark$ & & $\checkmark$ & $\checkmark$ & $\checkmark$ & & $\checkmark$ & & & \\
\hline BWM & $\checkmark$ & $\checkmark$ & $\checkmark$ & $\checkmark$ & & $\checkmark$ & $\checkmark$ & & & $\checkmark$ & & & \\
\hline FELECTRE & $\checkmark$ & & $\checkmark$ & $\checkmark$ & & $\checkmark$ & $\checkmark$ & $\checkmark$ & & & & & \\
\hline FAHP & $\checkmark$ & & $\checkmark$ & $\checkmark$ & & $\checkmark$ & $\checkmark$ & & & & & & \\
\hline FAHP-TOPSIS & $\checkmark$ & $\checkmark$ & $\checkmark$ & & $\checkmark$ & $\checkmark$ & $\checkmark$ & $\checkmark$ & & $\checkmark$ & & $\checkmark$ & \\
\hline FAHP & $\checkmark$ & $\checkmark$ & $\checkmark$ & & & & & $\checkmark$ & & & & & \\
\hline FANP & $\checkmark$ & & & $\checkmark$ & & $\checkmark$ & & $\checkmark$ & & & & & $\sqrt{ }$ \\
\hline ANP-ELECTRE & $\checkmark$ & $\checkmark$ & $\checkmark$ & $\checkmark$ & & & $\checkmark$ & $\checkmark$ & & $\checkmark$ & & & $\sqrt{ }$ \\
\hline $\begin{array}{l}\text { DANP-FTOPSIS- } \\
\text { MSGP \& DANP- } \\
\text { FVIKOR }\end{array}$ & $\checkmark$ & & $\checkmark$ & & & $\checkmark$ & & $\checkmark$ & & $\checkmark$ & & & $\checkmark$ \\
\hline AHP & $\checkmark$ & $\checkmark$ & $\checkmark$ & & & & & $\checkmark$ & & & & & \\
\hline FDEMATEL & $\checkmark$ & $\checkmark$ & & & $\checkmark$ & $\checkmark$ & $\checkmark$ & $\checkmark$ & & $\checkmark$ & & & $\checkmark$ \\
\hline SCOR-TOPSIS & & & $\checkmark$ & & & $\checkmark$ & & & & & $\checkmark$ & & $\checkmark$ \\
\hline FTOPSIS-SWOT & $\checkmark$ & $\checkmark$ & $\checkmark$ & $\checkmark$ & & & $\checkmark$ & $\checkmark$ & $\checkmark$ & $\checkmark$ & & & \\
\hline FVIKOR & $\checkmark$ & $\checkmark$ & $\checkmark$ & $\checkmark$ & & & & & & & & & \\
\hline TOTAL & 20 & 14 & 20 & 13 & 4 & 10 & 10 & 15 & 4 & 9 & 2 & 1 & 5 \\
\hline
\end{tabular}

Source: Arabzad, et al., 2014; Bahadori, et al., 2017; Bali, S., 2017; Dargi, et al., 2014; Dweiri, et al., 2016; Jain, et al., 2016; Junior \& Osiro, 2014; Junior \& Carpinetti, 2016; Kumar, et al. 2018; Mirmousa \& Dehnavi, 2016; Rezaei, et al., 2014; Rezaei, et al., 2016; Rouyendegh \& Saputro, 2014; Sivrikaya, et al., 2015; Sarkar, et al., 2018; Sureeyatanapas, et al., 2018; Wan, et al., 2017; Wu, et al., 2016; Zhang, et al., 2015; and Zhong \& Yao, 2017

The other consideration made in using AHP \& TOPSIS methods in this study is the strengths of those methods relative to those of other alternative MCDM as summarized in Table 3.

Table 3 Strengths and Weaknesses of the MCDM Method

\begin{tabular}{|c|c|c|}
\hline Method & Strengths & Weaknesses \\
\hline $\begin{array}{l}\text { AHP (Analytical } \\
\text { Hierarchy } \\
\text { Process) }\end{array}$ & $\begin{array}{l}\text { 1. AHP is a decision selection method which } \\
\text { combines qualitative analysis and } \\
\text { quantitative analysis. (Liu, et al., 2017) } \\
\text { 2. AHP method is the most widely used } \\
\text { method of analysis for decision making } \\
\text { nowadays (Kurniawan et al., 2018). AHP is } \\
\text { the Multi Criteria Decision Making } \\
\text { (MCDM) method that is most often used by } \\
\text { researchers due to its ease and versatility } \\
\text { with high accuracy. }\end{array}$ & $\begin{array}{l}\text { 1. Decision making using the AHP } \\
\text { method is often hampered by data } \\
\text { limitations and doubts such as } \\
\text { incomplete or unreliable data and } \\
\text { vague and subjective information due } \\
\text { to dependence on human experts. } \\
\text { (Shapiro and Koissi, 2017) } \\
\text { 2. Calculations using the AHP method are } \\
\text { very time-consuming and have } \\
\text { complex structures when used to solve }\end{array}$ \\
\hline
\end{tabular}




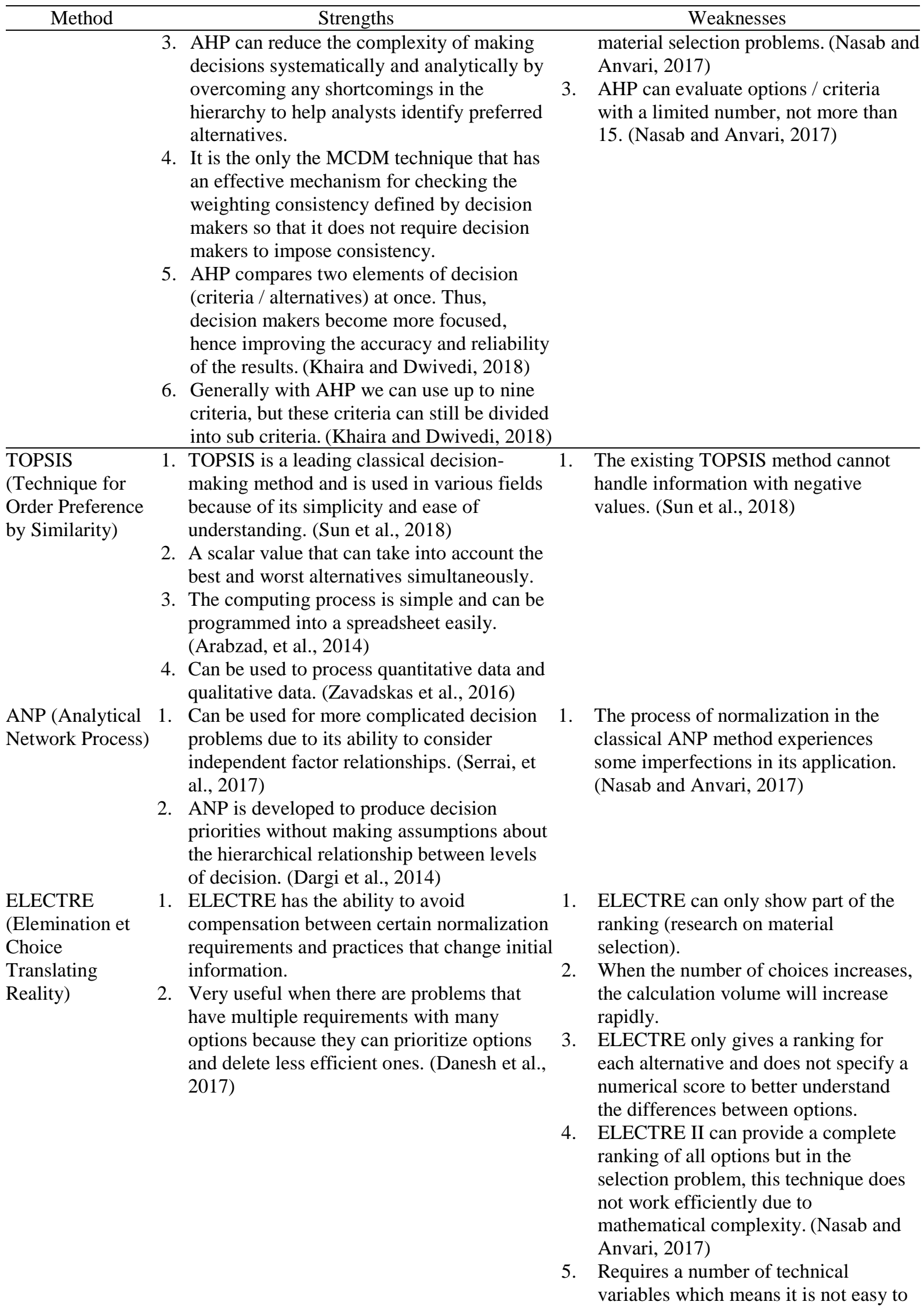




\begin{tabular}{|c|c|c|}
\hline Method & Strengths & Weaknesses \\
\hline GTMA & - & $\begin{array}{l}\text { fully understand. (Danesh et al., 2017) } \\
\text { 1. Often limited to problems with only } 5 \\
\text { or } 6 \text { criteria due to difficult calculation } \\
\text { procedures. (Nasab and Anvari, 2017) }\end{array}$ \\
\hline PROMETHEE & $\begin{array}{l}\text { 1. PROMETHEE has a clearer calculation } \\
\text { process and smaller computational effort } \\
\text { when compared to a very complicated } \\
\text { ELECTRE calculation. (Nasab and Anvari, } \\
\text { 2017) }\end{array}$ & $\begin{array}{l}\text { 1. It has limitations in designing problems } \\
\text { and identifying weights. } \\
\text { 2. PROMETHEE is unable to rank perfect } \\
\text { options. (Nasab and Anvari, 2017) }\end{array}$ \\
\hline VIKOR & $\begin{array}{l}\text { 1. By using linear standardization, calculations } \\
\text { are not affected by individual indicator units. } \\
\text { (Wu et al., 2016) }\end{array}$ & $\begin{array}{l}\text { 1. There are no tools / tools designed to } \\
\text { execute the VIKOR method. } \\
\text { 2. It is difficult to deal with incomplete } \\
\text { and uncertain data and experience } \\
\text { problems in ranking reversals. (Danesh } \\
\text { et al., 2017) }\end{array}$ \\
\hline
\end{tabular}

Source: Arabzad, et al., 2014; Danesh et al., 2017; Dargi et al., 2014; Khaira and Dwivedi, 2018; Kurniawan et al., 2018; Liu, et al., 2017; Nasab and Anvari, 2017; Serrai, et al., 2017; Shapiro and Koissi, 2017; Sun et al., 2018; Zavadskas et al., 2016; and Wu et al., 2016

\section{RESEARCH METHODOLOGY}

This research is quantitative research. PT.X Company was considered as the unit of analysis. Time horizon in this study was cross-sectional. Primary data was obtained from questionnaires and interviews with procurement staff and procurement managers, while the secondary data was obtained from literature studies.

Data analysis using the AHP and AHP-TOPSIS methods was carried out in several stages. First, the criteria, sub criteria, and alternative suppliers were identified. Second, data was collected using interviews and questionnaires. Third, the weight of each criterion and sub criterion was determined using the AHP method. Fourth, supplier alternative priorities were calculated using AHP and AHP-TOSIS methods. Lastly, the calculation results were analyzed and compared using AHP and AHP-TOPSIS, conclusions were drawn and recommendations made.

Based on the information in Table 2, the most frequently used criteria in supplier selection are quality, price, delivery, profile, relationships, costs, performance, service, location, capabilities, documents, brands, and risks. Gurung and Phipon (2016), conducted a supplier selection study on ten alternative suppliers using the AHP method for weighting and the TOPSIS method for sorting alternative supplier priorities based on four criteria namely product quality, facilities, delivery time, and price; it was determined that the sixth supplier (S6) was the best supplier alternative. Devi and Wardhana (2018) conducted research on the selection of the best suppliers of a department store Kopetri using the AHP method and the TOPSIS method based on four criteria namely quality, delivery, service, and price, based on the highest weighted criteria. Compared to the two previous studies, this study divides each criterion into other sub criteria, which aim to further detail the aspects that are taken into consideration in the procurement of diesel fuel suppliers.

From the literature studies and results of interviews with the procurement manager at PT. X, six criteria and 23 sub criteria were obtained, which are the basis for consideration in the selection of diesel fuel suppliers at PT. $X$. These criteria and sub criteria can be seen in Table 4. The criteria used in this study are quality, price, capability, delivery, supplier profile, and services \& relations. The sub criteria of each criterion can be seen in Table 3. 
Table 4 Criteria and Sub criteria in the Selection of Diesel Fuel Suppliers

\begin{tabular}{|c|c|}
\hline Criteria & Sub criteria \\
\hline \multirow[t]{2}{*}{ Quality } & (Q1) Product specification \\
\hline & $\begin{array}{l}\text { (Q2) Brand } \\
\text { (Q3) Brand reputation }\end{array}$ \\
\hline \multirow[t]{4}{*}{ Price } & (P1) Product price \\
\hline & (P2) Delivery cost \\
\hline & (P3) Taxes \\
\hline & (P4) Payment term \\
\hline \multirow[t]{2}{*}{ Capability } & (C1) Supply capacity \\
\hline & (C2) Production capacity \\
\hline \multirow[t]{5}{*}{ Delivery } & (D1) Accuracy of delivery time \\
\hline & (D2) Accuracy of delivery quantity \\
\hline & (D3) Choice of transportation \\
\hline & (D4) Availability of transportation units \\
\hline & (D5) Lead time \\
\hline \multirow[t]{3}{*}{ Supplier Profile } & (S1) Reputation \\
\hline & (S2) Procedural compliance \\
\hline & (S3) Verified supplier \\
\hline \multirow[t]{6}{*}{ Service \& Relationship } & (R1) Communication \\
\hline & (R2) Flexibility \\
\hline & (R3) Long-term relationship \\
\hline & (R4) After-sales service \\
\hline & (R5) Response time \\
\hline & (R6) Cooperative \\
\hline
\end{tabular}

Source: PT. X (2018)

\section{RESUlt AND DisCUSSION}

Based on the results of interviews with PT. X, nine alternative suppliers were identified for the four operational areas of PT. X, namely the provinces of South Sumatra, Central Kalimantan, West Kalimantan, and East \& North Kalimantan. The suppliers are as shown in Table 5.

Table 5 List of Alternative Diesel Fuel Suppliers at PT. X

\begin{tabular}{llc}
\hline \multicolumn{1}{c}{ Province } & Alternative Suppliers & $\begin{array}{c}\text { Code of Alternative } \\
\text { Suppliers }\end{array}$ \\
\hline South Sumatra & Alternative Supplier 1 & ASS1 \\
& Alternative Supplier 2 & ASS2 \\
& Alternative Supplier 3 & ASS3 \\
\hline Central Kalimantan & Alternative Supplier 1 & AST1 \\
& Alternative Supplier 2 & AST2 \\
\hline West Kalimantan & Alternative Supplier 1 & ASB1 \\
& Alternative Supplier 2 & ASB2 \\
\hline \multirow{2}{*}{ East \& North Kalimantan } & Alternative Supplier 1 & ASK1 \\
& Alternative Supplier 2 & ASK2 \\
\hline
\end{tabular}

Source: PT. X (2018)

After getting a list of criteria and sub criteria as well as supplier alternatives that will be examined, the next step is to create the AHP hierarchy structure as shown in Figure 2. After the criteria, sub criteria, and alternative diesel fuel suppliers have been determined, the next step is the data collection process, which was carried out using a paired comparison questionnaire. The basis of the assessment can be seen in Table 6. From the paired comparison questionnaire which is filled by a procurement specialist and procurement manager at PT. X, the data obtained will be fed into the paired comparison matrix shown in Table 7. Similar pairing comparison 
matrices were also run on the results of the questionnaire against the sub criteria assessment in the selection of diesel fuel suppliers.

Table 6 Scale Weight Ratio

\begin{tabular}{cl}
\hline Weight & \multicolumn{1}{c}{ Description } \\
\hline 1 & Both elements are equally important \\
3 & One element is a little more important than the other elements \\
5 & One element is more important than the other \\
7 & One element is clearly more important than other elements \\
9 & One element is absolutely important than the other elements \\
$2,4,6,8$ & Values between two values of adjacent considerations
\end{tabular}

Source: Mu \& Rojas (2017)

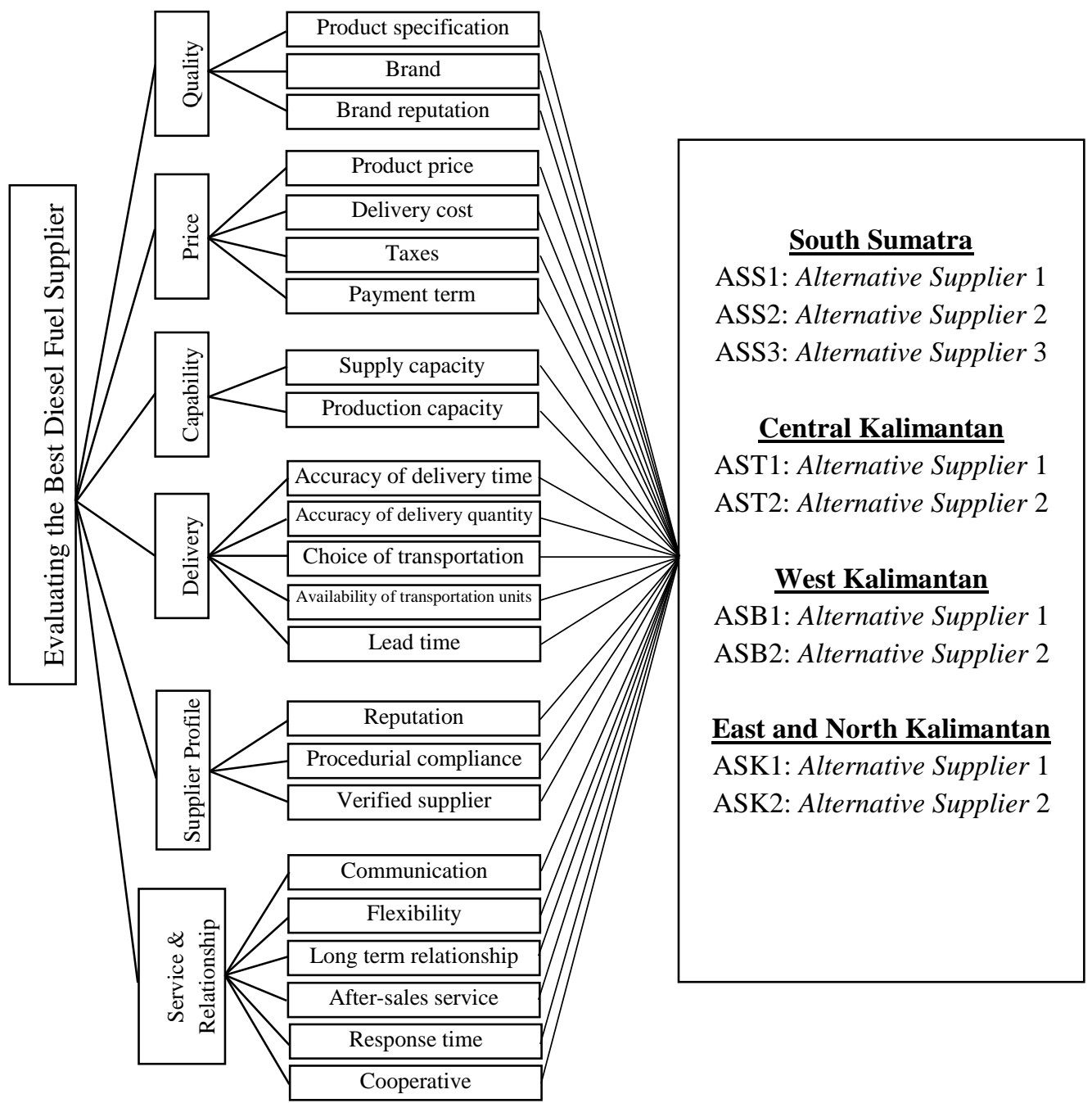

Figure 2 AHP Hierarchy Structure for the Selection of Diesel Fuel Suppliers (Source: Data processing, 2018) 
Table 7 Pairing Comparison Matrix Criteria for Respondent 1

\begin{tabular}{ccccccc}
\hline \multicolumn{7}{c}{ Respondent 1_Criteria } \\
\hline R1 & Q & P & C & D & S & R \\
\hline Q & 1 & 3 & 1 & 1 & 3 & 3 \\
P & 0.333 & 1 & 0.333 & 0.20 & 0.20 & 0.333 \\
C & 1 & 3 & 1 & 0.333 & 0.333 & 1 \\
D & 1 & 5 & 3 & 1 & 1 & 1 \\
S & 0.333 & 5 & 3 & 1 & 1 & 3 \\
R & 0.333 & 3 & 1 & 1 & 0.333 & 1 \\
\hline Total & 4 & 20 & 9.333 & 4.533 & 5.867 & 9.333 \\
\hline
\end{tabular}

Source: Data processing (2018)

Table 8 Pairing Comparison Matrix Criteria for Respondent 2

\begin{tabular}{ccccccc}
\hline \multicolumn{7}{c}{ Respondent 2_Criteria } \\
\hline R2 & $\mathbf{Q}$ & $\mathbf{P}$ & $\mathbf{C}$ & $\mathbf{D}$ & $\mathbf{S}$ & $\mathbf{R}$ \\
\hline $\mathrm{Q}$ & 1 & 3 & 0.333 & 0.143 & 5 & 3 \\
$\mathrm{P}$ & 0.333 & 1 & 0.20 & 0.20 & 5 & 3 \\
$\mathrm{C}$ & 3 & 5 & 1 & 0.333 & 7 & 5 \\
$\mathrm{D}$ & 7 & 5 & 3 & 1 & 9 & 7 \\
$\mathrm{~S}$ & 0.20 & 0.20 & 0.143 & 0.111 & 1 & 0.333 \\
$\mathrm{R}$ & 0.333 & 0.333 & 0.20 & 0.143 & 3 & 1 \\
\hline Total & 11.867 & 14.533 & 4.876 & 1.930 & 30 & 19.333 \\
\hline
\end{tabular}

Source: Data processing (2018)

Furthermore, the criteria and sub criteria comparison paired matrix was calculated using the AHP method to determine the weights of each criterion and its sub criteria. The calculations were carried out by first normalizing the pairwise comparison matrix and then calculating the consistency of the data obtained. After normalization and consistency calculations were complete, the next step was to perform geometric calculations of the mean to determine the absolute value of the two results of the questionnaire. The results of geometric mean calculations for the criteria can be seen in Table 9. The results of geometric mean calculations for the sub criteria can be seen in Table 10.

Table 9 Geometric Mean Criteria

\begin{tabular}{ccccc}
\hline \multirow{2}{*}{ Criteria } & R1 & R2 & \multicolumn{2}{c}{ Geometric Mean } \\
\cline { 2 - 5 } & Weight & Weight & Weight & Normalized \\
\hline Quality & 0.260 & 0.126 & 0.181 & 0.202 \\
Price & 0.047 & 0.094 & 0.067 & 0.074 \\
Capability & 0.124 & 0.244 & 0.174 & 0.194 \\
Delivery & 0.220 & 0.455 & 0.316 & 0.352 \\
Supplier Profile & 0.228 & 0.028 & 0.080 & 0.089 \\
Service \& Relationship & 0.121 & 0.053 & 0.080 & 0.089 \\
\hline & \multicolumn{2}{c}{ Sum of Geometric Mean } & 0.898 & 1.000 \\
\hline
\end{tabular}

Source: Data processing (2018)

Table 10 Geometric Mean Sub Criteria

\begin{tabular}{ccccc}
\hline Criteria \& & R1 & \multicolumn{2}{c}{ R2 } & \multicolumn{2}{c}{ Geometric Mean } \\
\cline { 2 - 5 } Sub criteria & Global Weight & Global Weight & Result & Normalized \\
\hline Quality & & & & \\
Q1 & 0.105 & 0.007 & 0.028 & 0.033 \\
Q2 & 0.030 & 0.057 & 0.041 & 0.049 \\
Q3 & 0.125 & 0.062 & 0.088 & 0.104 \\
\hline Price & & & & \\
P1 & 0.011 & 0.044 & 0.022 & 0.027
\end{tabular}




\begin{tabular}{ccccc}
\hline Criteria \& & R1 & R2 & \multicolumn{2}{c}{ Geometric Mean } \\
\cline { 2 - 5 } Sub criteria & Global Weight & Global Weight & Result & Normalized \\
\hline P2 & 0.009 & 0.038 & 0.019 & 0.022 \\
P3 & 0.004 & 0.004 & 0.004 & 0.005 \\
P4 & 0.022 & 0.008 & 0.013 & 0.016 \\
\hline Capability & & & & \\
C1 & 0.103 & 0.220 & 0.151 & 0.179 \\
C2 & 0.021 & 0.024 & 0.022 & 0.027 \\
\hline Delivery & & & & \\
D1 & 0.104 & 0.092 & 0.098 & 0.117 \\
D2 & 0.032 & 0.102 & 0.057 & 0.067 \\
D3 & 0.021 & 0.023 & 0.022 & 0.026 \\
D4 & 0.050 & 0.194 & 0.098 & 0.117 \\
D5 & 0.013 & 0.043 & 0.024 & 0.028 \\
\hline Supplier Profile & & & \\
S1 & 0.033 & 0.003 & 0.010 & 0.011 \\
S2 & 0.033 & 0.011 & 0.019 & 0.022 \\
S3 & 0.163 & 0.014 & 0.048 & 0.057 \\
\hline Service \& Relationship & & & \\
R1 & 0.005 & 0.010 & 0.007 & 0.008 \\
R2 & 0.032 & 0.013 & 0.020 & 0.024 \\
R3 & 0.019 & 0.008 & 0.012 & 0.014 \\
R4 & 0.012 & 0.001 & 0.004 & 0.004 \\
R5 & 0.011 & 0.006 & 0.008 & 0.010 \\
R6 & 0.043 & 0.015 & 0.025 & 0.030 \\
\hline & & & 0.841 & 1.000 \\
\hline
\end{tabular}

Source: Data processing (2018)

Next calculation was performed to determine the order of priority of each alternative supplier. In this study, the researchers used two methods to determine the order of priority, namely the AHP method and the TOPSIS method. Priority determination using AHP and TOPSIS methods begins with a calculation of the alternative geometric means as shown in Table 11 .

Table 11 Final Geometric Mean Sub Criteria

\begin{tabular}{cccc}
\hline \multirow{2}{*}{ Sub Criteria } & \multicolumn{3}{c}{ Final Geometric Mean Sub Criteria } \\
\cline { 2 - 4 } & ASS1 & ASS2 & ASS3 \\
\hline Q1 & 0.389 & 0.389 & 0.174 \\
Q2 & 0.389 & 0.389 & 0.174 \\
Q3 & 0.464 & 0.464 & 0.069 \\
P1 & 0.570 & 0.255 & 0.114 \\
P2 & 0.719 & 0.166 & 0.109 \\
P3 & 0.389 & 0.389 & 0.174 \\
P4 & 0.488 & 0.218 & 0.218 \\
C1 & 0.745 & 0.149 & 0.099 \\
C2 & 0.397 & 0.397 & 0.132 \\
D1 & 0.764 & 0.114 & 0.114 \\
D2 & 0.719 & 0.109 & 0.166 \\
D3 & 0.777 & 0.131 & 0.087 \\
D4 & 0.777 & 0.131 & 0.087 \\
D5 & 0.745 & 0.149 & 0.099 \\
S1 & 0.573 & 0.195 & 0.133 \\
S2 & 0.610 & 0.203 & 0.091 \\
S3 & 0.333 & 0.333 & 0.333 \\
R1 & 0.106 & 0.633 & 0.260 \\
R2 & 0.455 & 0.091 & 0.455 \\
\hline
\end{tabular}




\begin{tabular}{cccc}
\hline \multirow{2}{*}{ Sub Criteria } & \multicolumn{3}{c}{ Final Geometric Mean Sub Criteria } \\
\cline { 2 - 4 } & ASS1 & ASS2 & ASS3 \\
\hline R3 & 0.480 & 0.115 & 0.405 \\
R4 & 0.114 & 0.255 & 0.570 \\
R5 & 0.570 & 0.255 & 0.114 \\
R6 & 0.333 & 0.333 & 0.333 \\
\hline
\end{tabular}

Source: Data processing (2019)

To calculate the priority sequence using the AHP method, the geometric mean is multiplied by each weight of the sub criteria and summed for each alternative supplier until an AHP assessment is obtained for the alternative suppliers, which can then be rated. To calculate the priority sequence using the TOPSIS method, the first step taken was to normalize the geometric mean results, then the normalization results were multiplied with the weight of each sub criteria to obtain the weighted normalized decision matrix. The next step is to determine positive ideal solutions from the alternative suppliers. Then the separation measure, which is used to measure the distance between an alternative to the ideal positive solution and the ideal negative solution, is calculated. The last step is to calculate the relative proximity value to determine the preferences of each alternative supplier. From the step of supplier alternative priority calculation using the AHP and TOPSIS methods, the results of the two methods are as follows.

Table 12 Calculation Results of Diesel Fuel Suppliers' Selection in South Sumatra

\begin{tabular}{|c|c|c|c|c|c|c|}
\hline \multicolumn{7}{|c|}{ South Sumatera } \\
\hline \multirow{2}{*}{ Alternatives of Supplier } & \multicolumn{3}{|c|}{ AHP } & \multicolumn{3}{|c|}{ AHP-TOPSIS } \\
\hline & Result & Percentage & Rank & Result & Percentage & Rank \\
\hline Alternative Supplier 1 (ASS1) & 0.610 & $62.02 \%$ & 1 & 0.971 & $75.35 \%$ & 1 \\
\hline Alternative Supplier 2 (ASS2) & 0.226 & $22.96 \%$ & 2 & 0.251 & $19.46 \%$ & 2 \\
\hline Alternative Supplier 3 (ASS3) & 0.148 & $15.02 \%$ & 3 & 0.067 & $5.19 \%$ & 3 \\
\hline
\end{tabular}

Source: Data processing (2019)

Table 13 Calculation Results of Diesel Fuel Suppliers' Selection in Central Kalimantan

\begin{tabular}{ccccccc}
\hline \multicolumn{4}{c}{ Central Kalimantan } \\
Alternatives of Supplier & \multicolumn{3}{c}{ AHP } & \multicolumn{3}{c}{ AHP-TOPSIS } \\
\cline { 2 - 7 } & Result & Percentage & Rank & Result & Percentage & Rank \\
\hline Alternative Supplier 1 (AST1) & 0.622 & $62.80 \%$ & 1 & 0.658 & $65.81 \%$ & 1 \\
Alternative Supplier 2 (AST2) & 0.368 & $37.20 \%$ & 2 & 0.342 & $34.19 \%$ & 2 \\
\hline
\end{tabular}

Source: Data processing (2019)

Table 14 Calculation Results of Diesel Fuel Suppliers' Selection in West Kalimantan

\begin{tabular}{ccccccc}
\hline & \multicolumn{3}{c}{ West Kalimantan } & \multicolumn{3}{c}{ AHP-TOPSIS } \\
\hline \multirow{2}{*}{ Alternatives of Supplier } & \multicolumn{3}{c}{ AHP } & Result & Percentage & Rank \\
\cline { 2 - 7 } & Result & Percentage & Rank & 1.000 & $100.00 \%$ & 1 \\
\hline Alternative Supplier 1 (ASB1) & 0.751 & $79.79 \%$ & 1 & 0.000 & $0.00 \%$ & 2 \\
Alternative Supplier 2 (ASB2) & 0.190 & $20.21 \%$ & 2 & 0 &
\end{tabular}

Source: Data processing (2019)

Table 15 Calculation Results of Diesel Fuel Suppliers' Selection in East \& North Kalimantan

\begin{tabular}{ccccccc}
\hline \multicolumn{3}{c}{ East and North Kalimantan } \\
Alternatives of Supplier & \multicolumn{3}{c}{ AHP } & \multicolumn{3}{c}{ AHP-TOPSIS } \\
\cline { 2 - 7 } & Result & Percentage & Rank & Result & Percentage & Rank \\
\hline Alternative Supplier 1 (ASK1) & 0.660 & $71.31 \%$ & 1 & 0.917 & $91.65 \%$ & 1 \\
Alternative Supplier 2 (ASK2) & 0.265 & $28.69 \%$ & 2 & 0.083 & $8.35 \%$ & 2 \\
\hline
\end{tabular}

Source: Data processing (2019) 
To get the final weighting results corresponding to the alternative suppliers, then each supplier's alternate mean geometric weights is multiplied by each geometric mean global weight of each sub criterion. The total weight, which is mentioned in "Result" column from Table 12 to Table 15, can be made to be 1 or $100 \%$, by indicating their proportional scores as calculated in the "Percentage" column.

\section{CONCLUSION}

The first conclusion of this research is about the criteria and sub criteria used in selecting diesel fuel suppliers at PT. X, there are six criteria consisting of quality, price, capability, delivery, supplier profile, and service \& relations. The quality criterion consists of three sub criteria, namely product specifications, brands and brand reputation. The price criterion consists of four sub criteria namely product price, shipping cost, tax, and payment method. The capability criterion consists of two sub criteria namely supply capability and production capability. The shipping criterion consists of five sub criteria, namely timeliness of delivery, accuracy of delivery amount, transportation fleet selection, transportation fleet availability, and lead time. Supplier profile criterion consists of three sub criteria, namely supplier reputation, procedure compliance, and verified supplier. The last criterion is the service \& relations criterion, which consists of six sub criteria namely communication, flexibility, long-term relationship, after-sales service, response time, and cooperation.

The second conclusion is about the weight obtained from the calculation using the AHP method where the criterion with the highest weighting was delivery, with a weight of 0.352 , followed by the quality criterion with a weight of 0.202 . The criterion that has the lowest weight is price with a weight of 0.074 . The sub criterion with the highest weighting is the supply capability with a weight of 0.179 , followed by timeliness of delivery with a weight of 0.1168 and transportation fleet availability with a weight of 0.1166 .

The third conclusion is that alternative supplier one is the best alternative supplier of diesel fuel in South Sumatra Province, Central Kalimantan Province, West Kalimantan Province, and East Kalimantan \& North Kalimantan Provinces. This conclusion is drawn from the confirmation that the four suppliers have the highest priority sequence according to the calculation performed using the AHP method, and have the shortest distance from the positive ideal solution and the farthest distance from the negative ideal solution according to the calculation performed using the TOPSIS method.

The fourth conclusion is from the comparison of the calculation results of alternative diesel fuel supplier priorities using the AHP method and the TOPSIS method in the four regions of PT. X, the result is the same priority sequence with slightly different weights. Determination of the alternative supplier priorities using the TOPSIS method has advantages in the form of more accurate calculations by considering the closest distance to the positive ideal solution and the longest distance to the ideal negative solution. Although TOPSIS gives priority results that are more accurate, the AHP method is a good and reliable approach for giving the criteria and sub criteria weights used in this study.

The suggestion from this research is that companies should place more emphasis on the price criterion given the contribution of diesel fuel as the second largest component in the allocation of corporate expenses for the purchase of non service materials. The second suggestion is for companies to implement the AHP or AHPTOPSIS methods because both of these methods can help companies in making supplier selection decisions. The third suggestion is that companies should apply the AHP and AHP-TOPSIS methods in selecting suppliers of materials other than diesel fuel, as well as to assist them in making other decisions. For further research, this study can be used as a reference for supplier selection using the AHP and the TOPSIS methods.

\section{REFERENCES}

Arabzad, S. M., Ghorbani, M., Razmi, J., \& Shirouyehzad, H. (2014). Employing Fuzzy TOPSIS and SWOT for Supplier Selection and Order Allocation Problem. The International Journal of Advanced Manufacturing Technology, 803-818.

Bahadori, M., Hosseini, S. M., Teymourzadeh, E., Ravangard, R., Raadabadi, M., \& Alimohammadzadeh, K. (2017). A Supplier Selection Model for Hospitals Using a Combination of Artificial Neural Network and Fuzzy VIKOR. International Journal of Healthcare Management, 1-9. 
Bali, S. (2017). An Analytical Framework for Supplier Evaluation and Selection: A Multi-Criteria Decision Making Approach. Int. J. Advanced Operations Management, 9, 1, 57-72.

Chi, H. T., \& Trinh, D. H. (2016). Supplier Selection by Using AHP-TOPSIS and Goal Programming - A Case Study in Casumina Rubber Company - Vietnam. MATEC Web of Conferences 68, 02002.

CNN Indonesia. (2018). Harga CPO Anjlok, Pemerintah Kaji Ulang Pungutan Sawit. Retrieved November 09, 2018, from CNN Indonesia: https://www.cnnindonesia.com/ekonomi/20181101145435-532343235/harga-cpo-anjlok-pemerintah-kaji-ulang-pungutan-sawit

CNN Indonesia. (2018). Harga CPO Anjlok, Pemerintah Turunkan Harga Pasar Biodiesel. Retrieved November 09, 2018, from CNN Indonesia: https://www.cnnindonesia.com/ekonomi/20181106204520-85344519/harga-cpo-anjlok-pemerintah-turunkan-harga-pasar-biodiesel

Danesh, D., Ryan, M. J., \& Abbasi, A. (2017). A Systematic Comparison of Multi-Criteria Decision Making Methods for the Improvement of Project Portfolio Management in Complex Organisations. Int. J. Management and Decision Making 16, 280-320.

Dargi, A., Anjomshoae, A., Galankashi, M. R., Memari, A., \& Tap, M. B. (2014). Supplier Selection: A FuzzyANP Approach. Procedia Computer Science 31, 691-700.

Devi, D. K., \& Wardhana, A. (2018). Analysis and Design of the Best Supplier Selection Case Study: Department Store Kopetri with the AHP and TOPSIS Methods. International Journal of Computer Science and Mobile Computing, 109-120.

Dweiri, F., Kumar, S., Khan, S. A., \& Jain, V. (2016). Designing an Integrated AHP based Decision Support System for Supplier Selection in Automotive Industry. Expert Sysems with Applications, 273-283.

Gurung, S., \& Phipon, R. (2016). Multi-Criteria Decision Making for Supplier Selection using AHP and TOPSIS Method. International Journal of Engineering Inventions, 13-17.

Hanung, R. (2018). Harga CPO Anjlok ke Level Terendah Dalam 3 Tahun. Retrieved November 09, 2018, from CNBC Indonesia: https://www.cnbcindonesia.com/market/20181102142925-17-40334/harga-cpo-anjlokke-level-terendah-dalam-3-tahun

Heizer, J., Render, B., \& Munson, C. (2017). Operations Management Sustainability and Supply Chain Management. United States of America: Pearson Education.

Jain, V., Sangaiah, A. K., Sakhuja, S., \& Thoduka, N. (2016). Supplier Selection using Fuzzy AHP and TOPSIS: A Case Study in the Indian Automotive Industry. Neural Computing and Applications, 555-564.

Junior, F. R., \& Carpinetti, L. C. (2016). Combining SCOR Model and Fuzzy TOPSIS for Supplier Evaluation. Int. J. Production Economics 174, 128-141.

Junior, F. R., \& Osiro, L. (2014). A Comparison Between Fuzzy AHP and Fuzzy TOPSIS Methods to Supplier Selection. Applied Soft Computing 21, 194-209.

Khaira, A., \& Dwivedi, R. (2018). A State of the Art Review of Analytical Hierarchy Process. Materials Today: Proceedings, 4029-4035.

Kumar, R., Padhi, S. S., \& Sarkar, A. (2018). Supplier Selection of an Indian Heavy Locomotive Manufacturer: An Integrated Approach Using Taguchi Loss Function, TOPSIS, and AHP. IIMB Management Review, 131.

Kumar, S., Kumar, S., \& Barman, A. G. (2018). Supplier Selection Using Fuzzy TOPSIS Multi Criteria Model for A Small Scale Steel Manufacturing Unit. Procedia Computer Science 133, 905-912.

Kurniawan, S., Nugraha, B.S., Yolanda, P. (2018). Analytical Hierarchy Process to Evaluate Supplier Performance in Timber Industry. Binus Business Review, 9(2), 133-143.

Liu, Y., Ni, W., \& Ge, Z. (2017). Fuzzy Decision Fusion System for Fault Classification with Analytic Hierarchy Process Approach. Chemometrics and Intelligent Laboratory Systems, 61-68.

Mousavi-Nasab, S. H., \& Sotoudeh-Anvari, A. (2017). A Comprehensive MCDM-based Approach using TOPSIS, COPRAS, and DEA as an Auxiliary Tool for Material Selection Problems. Material and Design $121,237-253$.

Mirmousa, S., \& Dehnavi, H. D. (2016). Development of Criteria of Selecting the Supplier by Using the Fuzzy DEMATEL Method. Procedia - Social and Behavioral Sciences 230, 281-289.

Mu, E., \& Pereyra-Rojas, M. (2017). Practical Decision Making An Introduction to the Analytic HIerarchy Process (AHP) Using Super Decisions V2. Switzerland: Springer.

Putriadita, D. (2018). Pasokan Melimpah, Harga CPO Tertekan. (Narita, Editor) Retrieved November 09, 2018, from Kontan: https://investasi.kontan.co.id/news/pasokan-melimpah-harga-cpo-tertekan

Renganath, K., \& Suresh, M. (2016). Supplier Selection Using Fuzzy MCDM Techniques: A Literature Review. 2016 IEEE International Conference on Computational Intelligence and Computing Research (ICCIC). 
Rezaei, J., Fahim, P. B., \& Tavasszy, L. (2014). Supplier Selection in the Airline Retail Industry Using a Funnel Methodology: Conjunctive Screening Method and Fuzzy AHP. Expert Systems with Application 41, 8165-8179.

Rezaei, J., Nispeling, T., Sarkis, j., \& Tavasszy, L. (2016). A Supplier Selection Life Cycle Approach Integrating Traditional and Environmental Criteria Using the Best Worst Method. Journal of Cleaner Production 135, 577-588.

Rouyendegh, B. D., \& Saputro, T. E. (2014). Supplier Selection Using Integrated Fuzzy TOPSIS and MCGP: A Case Study. Procedia Social and Behavioral Sciences 116, 3957-3970.

Sarkar, S., Pratihar, D. K., \& Sarkar, B. (2018). An Integrated Fuzzy Multiple Criteria Supplier Selection Approach and Its Application in A Welding Company. Journal of Manufacturing Systems, 163-178.

Serrai, W., Abdelli, A., Mokdad, L., \& Hammal, Y. (2017). Towards An Efficient and A More Accurate Web Service Selection Using MCDM Methods. Journal of Computational Science 22, 253-267.

Shapiro, A. F., \& Koissi, M.-C. (2017). Fuzzy Logic Modifications of the Analytic Hierarchy Process. Insurance: Mathematics and Economics, 189-202.

Sivrikaya, B. T., Kaya, A., Dursun, E., \& Cebi, F. (2015). Fuzzy AHP-Goal Programming Approach for a Supplier Selection Problem. Research in Logistics \& Production 5, 271-285.

Sun, G., Guan, X., Yi, X., \& Zhou, Z. (2018). An Innovative TOPSIS Approach Based on Hesitant Fuzzy Correlation Coefficient and Its Applications. Applied Soft Computing, 249-267.

Sureeyatanapas, P., Sriwattananusart, K., Niyamosoth, T., Sessomboon, W., \& Arunyanart, S. (2018). Supplier Selection Towards Uncertain and Unavailable Information: An Extension of TOPSIS Method. Operation Research Perspectives 5, 69-79.

Wan, S.-p., Xu, G.-1., \& Dong, J.-y. (2017). Supplier Selection using ANP and ELECTRE II in Interval 2-tuple Linguistic Environment. Information Sciences, 19-38.

Wu, Y., Chen, K., Zeng, B., Xu, H., \& Yang, Y. (2016). Supplier Selection in Nuclear Power Industry with Extended VIKOR Method under Linguistic Information. Applied Soft Computing 48, 444-457.

Zavadskas, E. K., Mardani, A., Turskis, Z., Jusoh, A., \& Nor, K. M. (2016). Development of TOPSIS Method to Solve Complicated Decision-Making Problems: An Overview on Developments from 2000 to 2015. International Journal of Information Technology \& Decision Making 15, 645-682.

Zhang, X., Deng, Y., Chan, F. T., \& Mahadevan, S. (2015). A Fuzzy Extended Analytic Network Process-Based Approach for Global Supplier Selection. Applied Intelligence 43, 760-772.

Zhong, L., \& Yao, L. (2017). An ELECTRE I-Based Multi-Criteria Group Decision Making Method With Interval Type-2 Fuzzy Numbers and Its Application to Supplier Selection. Applied Soft Computing 57, 556-576. 